\title{
Comparison of a commercial interferon-gamma release assay and tuberculin skin test for the detection of latent tuberculosis infection in Hong Kong arthritis patients who are candidates for biologic agents
}

\author{
H So *, Carol SW Yuen, Ronald ML Yip
}

\section{A B S T R A C T}

Introduction: It is universally agreed that screening for latent tuberculosis infection prior to biologic therapy is necessary, especially in endemic areas such as Hong Kong. There are still, however, controversies regarding how best to accomplish this task. The tuberculin skin test has been the routine screening tool for latent tuberculosis infection in Hong Kong for the past decade although accuracy is far from perfect, especially in patients who have been vaccinated with Bacillus Calmette-Guérin, who are immunocompromised, or who have atypical mycobacterium infection. The new interferon-gamma release assays have been shown to improve specificity and probably sensitivity. This study aimed to evaluate agreement between the interferon-gamma release assay and the tuberculin skin test in the diagnosis of latent tuberculosis infection in patients with arthritic diseases scheduled to receive biologic agents.

Methods: We reviewed 38 patients with rheumatoid arthritis, psoriatic arthritis, or spondyloarthritis at a local hospital in Hong Kong from August 2013 to April 2014. They were all considered candidates for biologic agents. The patients underwent both the interferon-gamma release assay (ASACIR.TB; A.TB) and the tuberculin skin test simultaneously. Concurrent medications were documented. Patients who tested positive for either test (ie A.TB+ or TST+) were prescribed treatment for latent tuberculosis if they were to be given biologic agents. All patients were followed up regularly for 1 year and the development of active tuberculosis infection was evaluated.

Results: Based on an induration of $10 \mathrm{~mm}$ in diameter as the cut-off value, 13 (34.2\%) of 38 patients had a positive tuberculin skin test. Of the 38 patients, 11 (28.9\%) also had a positive interferon-gamma release assay. The agreement between interferon-gamma release assay and tuberculin skin test was $73.7 \%$

This article was published on 27 Jan 2017 at www.hkmj.org. were TST-/A.TB+. When positive tuberculin skin test was defined as an induration of $5-\mathrm{mm}$ diameter, the agreement between the two tests improved with a kappa value of 0.47 . In that case, half of the patients had a positive tuberculin skin test; among them, nine were TST+/A.TB-. Only one was TST-/A.TB+. Subgroup analysis showed that the agreement between both tests improved further (kappa $=0.69)$ in patients not taking a concurrent systemic steroid. For patients prescribed systemic steroid, the agreement was only slight with a kappa value of 0.066 . Finally, none of the 38 patients, of whom 32 had an exposure to biologic agents, developed active tuberculosis during the 1-year follow-up period.

Conclusion: In a tuberculosis-endemic population, although $10-\mathrm{mm}$ diameter induration is the usual cut-off for a positive tuberculin skin test, the level of agreement between the interferon-gamma release assay and tuberculin skin test improved from fair to moderate when the cut-off was lowered to $5 \mathrm{~mm}$. A dual testing strategy of tuberculin skin test and interferon-gamma release assays appeared to be effective and should be pursued especially in patients who are on systemic steroid therapy. Nonetheless, the issue of potential overtreatment is yet to be evaluated.

\section{Hong Kong Med J 2017;23:246-50 DOI: $10.12809 / \mathrm{hkmj} 164880$}

H So *, MSc, FHKAM (Medicine)

CSW Yuen, BNurs, MSc

RML Yip, FHKCP, FHKAM (Medicine)

Department of Medicine and Geriatrics, Kwong Wah Hospital, Yaumatei, Hong Kong

* Corresponding author: h99097668@hotmail.com

An earlier version of this paper was presented at the ASM of the Hong Kong Society of Rheumatology held in Hong Kong on 22 November 2015.

New knowledge added by this study

In Hong Kong, a tuberculosis-endemic area, the level of agreement between tuberculin skin test (TST) and interferon-gamma release assay (IGRA) for detecting latent tuberculosis infection was only fair in arthritis patients scheduled to receive biologic therapy.

- Although $10 \mathrm{~mm}$ is the cut-off for positive TST according to the local guideline, the level of agreement between the two tests improved when a 5-mm cut-off was used.

Implications for clinical practice or policy

Dual testing strategy with TST and IGRA appeared to be effective and should be employed, especially in patients who are prescribed systemic steroid therapy. 


\section{Introduction}

The advent of biologic agents has revolutionised the treatment of patients with rheumatoid arthritis (RA), psoriatic arthritis (PSA), and spondyloarthritis (SPA). The outcome is now greatly improved. This, however, comes at the price of a clear heightened risk of active tuberculosis (TB) as a progression of latent TB infection (LTBI). ${ }^{1}$ Therefore, it is universally agreed that screening for LTBI prior to biologic therapy is necessary, especially in endemic areas such as Hong Kong. ${ }^{2}$ Unfortunately, there remains controversy regarding how best to accomplish this task.

The tuberculin skin test (TST) has been the routine screening tool in Hong Kong for the past decade. ${ }^{3}$ Its accuracy, however, is far from perfect, especially in patients who have been vaccinated with Bacillus Calmette-Guérin (BCG), are immunocompromised, or have been infected with atypical mycobacterium. ${ }^{4}$ Recently, interferon-gamma release assays (IGRAs) that measure interferon-gamma secretion in response to Mycobacterium tuberculosis-specific antigens have become available to detect LTBI. They have been shown to offer improved specificity and probably sensitivity. ${ }^{5,6}$ Other shortcomings of the TST, such as the need for return visits and reader variability, are also overcome. One of the IGRAs, the ASACIR.TB (A.TB; Haikou VTI Biological Institute, Hainan, China), has shown encouraging results in a largescale clinical trial conducted in China and might be more appropriate in Chinese populations. ${ }^{7}$

On the other hand, IGRAs are not flawless. The rate of indeterminate results has been reported to be as high as $40 \%{ }^{8}$ The immunocompromised state of arthritic patients will also induce a depressed response to a $\mathrm{T}$-cell reaction leading to an inaccurate IGRA result. There are recent data to argue that an IGRA alone is insufficient to identify all patients at risk. ${ }^{9,10}$ Furthermore, various studies have suggested very different concordance figures between the IGRA and the TST, likely as a result of heterogeneity (eg differing background TB prevalence, variable immunosuppressive therapies, or underlying BCG status). ${ }^{11}$

This study aimed to evaluate the agreement between the IGRA and the TST in the diagnosis of LTBI in patients with arthritic diseases scheduled to receive biologic agents in Hong Kong.

\section{Methods}

\section{Patients}

We reviewed 38 patients with RA, PSA, or SPA at a local hospital in Hong Kong from August 2013 to April 2014. They were diagnosed according to the 2010 classification criteria for RA of the American College of Rheumatology/European League Against

\section{可接受生物製劑治療的香港關節炎患者中以 $\gamma$-干擾素釋放試驗或結核菌素皮膚測試對檢測潛 伏結核分枝桿菌感染的比較}

\author{
蘇晧、袁思慧、葉文龍
}

引言：普遍認為，施行生物製劑治療前必須測試是否有潛伏結核分枝 桿菌感染, 尤其是結核病屬於風土病的香港等地區。然而, 如何能 達致最佳測試仍存在爭議。過去十年, 香港一直使用結核菌素皮膚 測試（TST）作為潛伏結核分枝桿菌感染的常規檢查。不過, 這種方 法始終無法達到完美精確度, 特別是對於曾接種卡介苗、免疫不全 或出現非典型分枝桿菌感染的患者。研究顯示新的 $\gamma$-干擾素釋放試驗 (IGRA) 可改善檢測的特異性, 甚至是敏感性。本研究旨在評估在 可接受生物製劑治療的香港關節炎患者中, 比較使用IGRA或TST檢測 潛伏結核分枝桿菌感染的一致率

方法：研究對象為 2013 年 8 月至 2014 年 4 月期間於香港一所醫院的類 風濕關節炎、銀屑病關節炎或脊柱關節病共 38 名患者, 他們同時進行 IGRA（ASACIR.TB；A.TB）和TST。這些患者均可能接受生物製劑 治療。我們記錄了患者在治療期間服用的藥物。兩種測試均呈陽性的 患者（即A.TB+或TST+）, 如果要給予生物製劑, 便會處方潛伏結核 分枝桿菌感染的藥物。所有患者定期隨訪 1 年來評估他們活性結核病 的情況

結果：38名患者中, 如果以硬結直徑為 $10 \mathrm{~mm}$ 的臨界值計算, 13 名 ( $34.2 \%)$ 的TST呈陽性反應, 11 名 $(28.9 \%)$ 的IGRA亦呈陽性反 應；IGRA和TST之間的一致性為 $73.7 \%$ （k值為0.39）。6名患者為 TST+/A.TB-, 4名為TST-/A.TB+。如果以硬結直徑為 $5 \mathrm{~mm}$ 的臨界值 計算, 兩種試驗之間的一致性有改善, $\mathrm{k}$ 值為 0.47 。一半患者的TST呈 陽性反應, 其中 9 例為TST+/A.TB-, 只有 1 例為TST-/A.TB $+\circ$ 亞組分 析顯示, 當患者無同時服用全身性類固醇時, 兩種試驗之間的一致性 進一步改善, $\mathrm{k}$ 值為 0.69 。相反, 當患者同時接受全身性類固醇治療 時, 兩種試驗之間的一致性較差, $\mathrm{k}$ 值為 0.066 。在 1 年隨訪期間, 全 部38名患者均無活性結核病; 其中 32 人曾服食生物製劑。

結論：在結核病屬於風土病的地方中, 當TST的硬結直徑臨界值由傳 統的 $10 \mathrm{~mm}$ 降至 $5 \mathrm{~mm}$ 時, IGRA和TST之間的一致性從普通水平改善 至中度水平。要測試是否有潛伏結核分枝桿菌感染, 讓患者同時進行 IGRA和TST似乎有效, 尤其應用在接受全身類固醇治療的患者當中。 儘管如此, 過度治療的風險尚待評估。

Rheumatism, the Classification Criteria for Psoriatic Arthritis, and the Assessment of SpondyloArthritis international Society classification criteria, respectively. Patients were included if they were considered candidates for biologic agents. Concurrent medications were documented. Candidates were excluded if they had active TB infection, a history of incomplete TB treatment, or no measured induration. Patients underwent both the IGRA and the TST simultaneously. Those who tested positive for either test and who were due to be prescribed biologic agents were given latent TB treatment with isoniazid or rifampicin for 9 months. All patients were followed up regularly for 1 year and the development of active TB infection was 
evaluated. This study conforms to the provisions of the Declaration of Helsinki and the guidelines of the local ethical committee. Informed consent was considered not necessary due to the retrospective nature of the study.

\section{Tuberculin skin test}

The TST was performed by rheumatologists. A $0.1 \mathrm{~mL}$ of 2-TU PPD (tuberculin units of purified protein derivative) was injected intradermally into the volar aspect of the forearm. The indurations were measured in millimetres after 48 hours of inoculation by rheumatologists who were blinded to the IGRA results. According to the local guideline, induration of $\geq 10 \mathrm{~mm}$ was considered a positive result of LTBI. ${ }^{3}$

\section{Interferon-gamma release assay}

We performed the A.TB IGRA test (Haikou VTI Biological Institute) in all study patients. This assay employs Haikou VTI's patented technology (US patent number 7754219) that enables intracellular delivery of the full-length protein CFP-10 and the antigen ESAT- 6 to stimulate antigen-specific T-cells through the major histocompatibility complex class 1 pathway. ${ }^{12,13}$ The assay was performed according to the user manual. In brief, negative control phosphate buffered saline $(\mathrm{N})$, positive control concanavalin $A$ (P), and the TB stimulators CFP-10 and ESAT-6 (T) were mixed with fresh heparinised whole blood and incubated for approximately 24 hours at $37.8^{\circ} \mathrm{C}$. The plasma was collected and stored at $48^{\circ} \mathrm{C}$ for up to 2 weeks. The interferon-gamma level in the plasma was then determined by enzyme-linked immunosorbent assay. If $\mathrm{N}$ was $<0.5 \mathrm{IU} / \mathrm{mL}$ and $(\mathrm{T}-\mathrm{N}) /(\mathrm{P}-\mathrm{N}) \geq 0.6$, or if $\mathrm{N}$ was $\geq 0.5 \mathrm{IU} / \mathrm{mL}$ and $(\mathrm{T}-\mathrm{N}) /(\mathrm{P}-\mathrm{N}) \geq 0.85$, the test was considered to be positive $(\mathrm{A} . \mathrm{TB}+)$, otherwise the result was negative (A.TB-).

\section{Statistical analysis}

Descriptive statistics were presented as frequencies and means \pm standard deviations as appropriate. The concordance between TST and IGRA was evaluated by the Cohen's weighted $\mathrm{k}$ statistic. A kappa value of $>0.6$ represents substantial agreement, 0.41 to 0.60 moderate agreement, 0.21 to 0.40 fair agreement, and $<0.21$ slight agreement. The concordance was subanalysed in patients with and without prednisolone.

\section{Results}

The demographic and clinical characteristics of 38 patients are summarised in Table 1 . All patients were residents of Hong Kong. Half of the patients were prescribed systemic steroid therapy that comprised prednisolone at a dose of $2.5 \mathrm{mg}$ daily to $15 \mathrm{mg}$ daily. All except three patients with SPA were on various conventional disease-modifying antirheumatic drugs.
TABLE I. Demographic and clinical characteristics of patients

\begin{tabular}{lc}
\hline Characteristic & $\begin{array}{c}\text { No. (\%) of } \\
\text { patients* }\end{array}$ \\
\hline Sex & $26(68.4)$ \\
\hline \multicolumn{1}{|c}{ Female } & $12(31.6)$ \\
\hline Rheumatoid arthritis & $24(63.1)$ \\
\hline Spondyloarthritis & $12(31.6)$ \\
\hline Psoriatic arthritis & $2(5.3)$ \\
\hline Mean ( \pm standard deviation) age (years) & $49.3 \pm 13.7$ \\
\hline Old tuberculosis changes on chest X-ray & $5(13.2)$ \\
\hline Prednisolone & $19(50.0)$ \\
\hline \multicolumn{1}{|c|}{ Mean dose (mg/day) } & 5.82 \\
\hline Methotrexate & $22(57.9)$ \\
\hline Sulphasalazine & $19(50.0)$ \\
\hline Leflunomide & $12(31.6)$ \\
\hline Hydroxychloroquine & $11(28.9)$ \\
\hline Cyclosporin A & $2(5.3)$ \\
\hline
\end{tabular}

* Unless otherwise stated

The results of the concomitant TST and IGRA are shown in Table 2 . Of the 38 patients, based on an induration of $10-\mathrm{mm}$ diameter as the cut-off value, 13 (34.2\%) had a positive TST, 11 (28.9\%) had a positive IGRA. The agreement between A.TB IGRA test and TST was $73.7 \%$. Six patients were TST+/A.TBand four were TST-/A.TB+. Subgroup analysis showed that four of the six divergent TST+/A.TBresults were in patients on systemic steroid, and only three patients with systemic steroid were A.TB+ versus eight patients without. When positive TST was defined as an induration of 5-mm diameter, half of the patients had a positive TST, among them nine were TST+/A.TB-. Only one was TST-/A.TB+. In patients prescribed a systemic steroid, with $5-\mathrm{mm}$ induration as positivity, TST missed no patients who had positive IGRAs.

Analysis of the agreement between the two tests, assessed by kappa statistic, showed only fair strength in our study, with a kappa value of 0.39 (Table 3). When a $5-\mathrm{mm}$ induration was taken as a positive TST, however, the agreement between the two tests improved to moderate with a kappa value of 0.47 . Subgroup analysis revealed that the agreement between both tests improved further (kappa=0.57) in patients not taking a concurrent systemic steroid. For patients taking a systemic steroid, the agreement was only slight (kappa=0.066). Again, the agreement of the TST and IGRA was substantial (kappa=0.69) in patients not on systemic steroid therapy when a 5-mm induration was regarded as positive.

At the end of the study, 32 of the initial 38 patients had received biologic agents. None of them 
TABLE 2. Tuberculin skin test (TST) and A.TB* test results

\begin{tabular}{lcccc}
\hline & TST+/A.TB+ & TST-/A.TB- & TST+/A.TB- & TST-/A.TB+ \\
\hline All patients, with 10-mm induration as cut-off $(\mathrm{n}=38)$ & 7 & 21 & 6 & 4 \\
Patients on prednisolone $(\mathrm{n}=19)$ & 1 & 12 & 4 & 2 \\
Patients not on prednisolone $(\mathrm{n}=19)$ & 6 & 9 & 2 & 2 \\
All patients, with 5-mm induration as cut-off $(\mathrm{n}=38)$ & 10 & 18 & 9 & 3 \\
Patients not on prednisolone, with 5-mm induration as cut-off $(\mathrm{n}=19)$ & 8 & 8 & 3 \\
\hline
\end{tabular}

* A.TB denotes ASACIR.TB interferon-gamma release assay

TABLE 3. Agreement between the two tests

\begin{tabular}{lccc}
\hline & K statistics & Standard error & Strength of agreement \\
\hline All patients, with 10-mm induration as cut-off $(n=38)$ & 0.39 & 0.16 & Fair \\
All patients, with 5-mm induration as cut-off $(n=38)$ & 0.47 & 0.13 & Moderate \\
Patients on prednisolone $(n=19)$ & 0.066 & 0.23 & Slight \\
Patients not on prednisolone $(n=19)$ & 0.57 & 0.16 & Moderate \\
Patients not on prednisolone, with 5-mm induration as cut-off $(n=19)$ & 0.69 & 0.16 & Substantial \\
\hline
\end{tabular}

developed active TB during the 1-year follow-up period.

\section{Discussion}

In clinical practice there is no gold standard test for diagnosing LTBI. Both IGRA and TST have strengths and weaknesses. In a meta-analysis performed on an unselected population, the specificity of IGRA was 99\% in a non-BCG-vaccinated population and $96 \%$ in a BCG-vaccinated population. ${ }^{14}$ The specificity of the TST was $97 \%$ in a non-BCG-vaccinated population but dropped to 59\% in a BCG-vaccinated population. ${ }^{14}$ In addition to BCG history, comparison between the two tests must take into account the underlying disease, the immunosuppression status, and the background TB burden of the population being screened.

In this study, we found only a fair agreement (kappa $=0.39)$ between the results of TST and A.TB IGRA in arthritis patients from a TB-endemic area. Some studies have also reported a discrepancy between the two tests in countries with intermediate TB burden. ${ }^{15,16}$ Nonetheless, the reported agreement between TST and the IGRA was good in countries with low-endemic TB (kappa of 0.72 in United Kingdom ${ }^{17}$ and 0.87 in Denmark $\left.{ }^{18}\right)$. Consequently, the incidence of $\mathrm{TB}$ is a crucial determinant of agreement between the two tests.

In this study the concordance between the TST and the IGRA was also affected by immune status. There was only slight agreement in patients taking concurrent prednisolone, but the agreement improved when these patients were excluded from the analysis. Some previous studies of immunosuppressed RA patients have shown similarly poor concordance between the two tests regardless of TB burden. ${ }^{19,20}$ There was also discordance between the two tests in LTBI diagnosis among individuals infected with the human immunodeficiency virus. ${ }^{21}$ The patients on prednisolone in our study had a lower rate of positivity for both tests. It seems intuitive to assume that an immunosuppressed state will induce a depressed response to a T-cell reaction. In the literature, a systematic review showed that both positive IGRA and positive TST results were significantly influenced by immunosuppressive therapy. ${ }^{22}$

The Hong Kong guideline for the TST cut-off value for LTBI diagnosis before anti-tumour necrosis factor treatment is an induration of $>10 \mathrm{~mm} .{ }^{3}$ In the current study, we showed that the TST cut-off value that achieved better agreement between IGRA and TST results was $5 \mathrm{~mm}$. If we cannot rely on IGRA to diagnose LTBI, it may be more appropriate to lower that TST cut-off to $5 \mathrm{~mm}$. We also showed that our approach to LTBI screening with both TST and IGRA was successful in preventing the development of active TB in patients who would receive biologic therapy. This dual testing strategy might be especially applicable to patients on systemic steroid, as they are at higher risk of developing active $\mathrm{TB}$ and the two test results are more discordant. The consequent improved sensitivity will invariably lower the 
specificity and cause a potential overtreatment. In these high-risk settings, however, it is reasonable to favour sensitivity in screening for LTBI.

Only five patients could give a definite history of BCG vaccination. For other patients, such information was uncertain. While this might reflect the local clinical situation, it is one of the limitations of the present study. Despite the mechanistic similarity, because of the different interpretation methods employed for the test results and the lack of comparative trials of the performance of A.TB IGRA and other IGRAs, the conclusions drawn from the current study may not be applicable to patients who are given a different IGRA. Further studies using individual IGRAs may be warranted to address the same question.

\section{Conclusion}

In arthritis patients in a TB-endemic population, the level of agreement between TST and A.TB IGRA for detecting LTBI was only fair. Although $10 \mathrm{~mm}$ is the usual cut-off for TST, the level of agreement between the two tests improved from fair to moderate when a 5-mm cut-off was used. A dual testing strategy with TST and IGRA appeared to be effective and should be pursued, especially in patients who are prescribed a systemic steroid. The issue of potential overtreatment is yet to be evaluated.

\section{Declaration}

All authors have disclosed no conflicts of interest.

\section{References}

1. Furst DE. The risk of infections with biologic therapies for rheumatoid arthritis. Semin Arthritis Rheum 2010;39:32746.

2. World Health Organization. Guidelines on the management of latent tuberculosis infection. Geneva, Switzerland: World Health Organization; 2015.

3. Mok CC. Consensus statements on the indications and monitoring of anti-tumor necrosis factor (TNF) therapy for rheumatic diseases in Hong Kong. Hong Kong Bull Rheum Dis 2005;5:19-25.

4. Huebner RE, Schein MF, Bass JB Jr. The tuberculin skin test. Clin Infect Dis 1993;17:968-75.

5. Matulis G, Jüni P, Villiger PM, Gadola SD. Detection of latent tuberculosis in immunosuppressed patients with autoimmune diseases: performance of a Mycobacterium tuberculosis antigen-specific interferon gamma assay. Ann Rheum Dis 2008;67:84-90.

6. Ponce de Leon D, Acevedo-Vasquez E, Alvizuri S, et al. Comparison of an interferon-gamma assay with tuberculin skin testing for detection of tuberculosis (TB) infection in patients with rheumatoid arthritis in a TB-endemic population. J Rheumatol 2008;35:776-81.

7. Song Q, Guo $\mathrm{H}$, Zhong $\mathrm{H}$, et al. Evaluation of a new interferon-gamma release assay and comparison to tuberculin skin test during a tuberculosis outbreak. Int J Infect Dis 2012;16:e522-6.

8. Ferrara G, Losi M, Meacci M, et al. Routine hospital use of a new commercial whole blood interferon-gamma assay for the diagnosis of tuberculosis infection. Am J Respir Crit Care Med 2005;172:631-5.

9. Kleinert S, Tony HP, Krueger K, et al. Screening for latent tuberculosis infection: performance of tuberculin skin test and interferon-gamma release assays under real-life conditions. Ann Rheum Dis 2012;71:1791-5.

10. Mariette X, Baron G, Tubach F, et al. Influence of replacing tuberculin skin test with ex vivo interferon gamma release assays on decision to administer prophylactic antituberculosis antibiotics before anti-TNF therapy. Ann Rheum Dis 2012;71:1783-90.

11. Winthrop KL, Weinblatt ME, Daley CL. You can't always get what you want, but if you try sometimes (with two tests-TST and IGRA-for tuberculosis) you get what you need. Ann Rheum Dis 2012;71:1757-60.

12. Cao H, Agrawal D, Kushner N, Touzjian N, Essex M, $\mathrm{Lu}$ Y. Delivery of exogenous protein antigens to major histocompatibility complex class I pathway in cytosol. J Infect Dis 2002;185:244-51.

13. McEvers K, Elrefaei M, Norris P, et al. Modified anthrax fusion proteins deliver HIV antigens through MHC class I and II pathways. Vaccine 2005;23:4128-35.

14. Pai M, Zwerling A, Menzies D. Systematic review: T-cellbased assays for the diagnosis of latent tuberculosis infection: an update. Ann Intern Med 2008;149:177-84.

15. Yilmaz N, Zehra Aydin S, Inanc N, Karakurt S, Direskeneli H, Yavuz S. Comparison of QuantiFERON-TB Gold test and tuberculin skin test for the identification of latent Mycobacterium tuberculosis infection in lupus patients. Lupus 2012;21:491-5.

16. Lee JH, Sohn HS, Chun JH, et al. Poor agreement between QuantiFERON-TB Gold test and tuberculin skin test results for the diagnosis of latent tuberculosis infection in rheumatoid arthritis patients and healthy controls. Korean J Intern Med 2014;29:76-84.

17. Ewer K, Deeks J, Alvarez L, et al. Comparison of Tcell-based assay with tuberculin skin test for diagnosis of Mycobacterium tuberculosis infection in a school tuberculosis outbreak. Lancet 2003;361:1168-73.

18. Brock I, Weldingh K, Lillebaek T, Follmann F, Andersen P. Comparison of tuberculin skin test and new specific blood test in tuberculosis contacts. Am J Respir Crit Care Med 2004;170:65-9.

19. Huang YW, Shen GH, Lee JJ, Yang WT. Latent tuberculosis infection among close contacts of multidrug-resistant tuberculosis patients in central Taiwan. Int J Tuberc Lung Dis 2010;14:1430-5.

20. Shalabi NM, Houssen ME. Discrepancy between the tuberculin skin test and the levels of serum interferongamma in the diagnosis of tubercular infection in contacts. Clin Biochem 2009;42:1596-601.

21. Mandalakas AM, Hesseling AC, Chegou NN, et al. High level of discordant IGRA results in HIV-infected adults and children. Int J Tuberc Lung Dis 2008;12:417-23.

22. Shahidi N, Fu YT, Qian H, Bressler B. Performance of interferon-gamma release assays in patients with inflammatory bowel disease: a systematic review and meta-analysis. Inflamm Bowel Dis 2012;18:2034-42. 